\title{
SYNTHESIS OF HYDROCARBON FUELS USING RENEWABLE AND NUCLEAR ENERGY
}

\author{
Ken Schultz \\ General Atomics, 3550 General Atomics Court, San Diego, CA 92121, ken.schultz@gat.com \\ S. Locke Bogart \\ General Atomics Consultant, 7982 Chaucer Drive, Weeki Wachee, FL 34607, lbogart@tampabay.rr.com \\ Richard P. Noceti \\ National Energy Technology Laboratory and LTI Associates, P.O. Box 178, Bannock, OH 43972.rnoceti@lti-global.com
}

\begin{abstract}
In light of the current issues of carbon control and the desire to become less dependent on imported oil, we propose to apply non-carbon-based energy supplies (renewables and nuclear) to reduction of $\mathrm{CO}_{2}$ emissions and production of liquid synthetic fuels. To this end we have performed technical and economic analyses of systems ranging from augmentation of coal-to-liquids processes, through the use of coal power plant $\mathrm{CO}_{2}$ to the extraction of atmospheric $\mathrm{CO}_{2}$ for the production of synthetic fuels.
\end{abstract}

This paper emphasizes the utilization of coal power plant $\mathrm{CO}_{2}$ and points towards the closure of the carbon cycle by the ultimate use of atmospheric $\mathrm{CO}_{2}$.

\section{INTRODUCTION}

Renewable and nuclear energy based production of synthetic hydrocarbon fuels ("synfuels") can help reduce $\mathrm{CO}_{2}$ emissions and address the growing shortage of petroleum. Refined petroleum products and synfuels can be generically expressed as $\left[\mathrm{CH}_{2}\right]_{\mathrm{n}}$, where $\mathrm{n}$ is significantly greater than two. Currently, synfuels are produced from coal and natural gas. With increasing natural gas prices, there will be a greater emphasis on coal as a feedstock. In coal-to-liquids (CTL) processes that go through gasification to synthesis gas [CO $\left.+\mathrm{H}_{2}\right]$, about one molecule of $\mathrm{CO}_{2}$ is made for every $\mathrm{CH}_{2}$ unit in the synfuel. Displacing petroleum with coal-based fuels for our transportation sector can be done in ways that will reduce $\mathrm{CO} 2$ emissions. This investigation explores the concepts of how renewable and nuclear energy could help the simultaneous problems of $\mathrm{CO}_{2}$ emissions and dwindling petroleum supplies.

The production rate of $\mathrm{CO}_{2}$ from coal electric power plants in the US is $\sim 1,894$ million metric tons/year. If this $\mathrm{CO}_{2}$ were captured using proven processes and used with hydrogen produced by solar, wind or nuclear energy to make synfuel, it would provide all the hydrocarbon fuel needed for our transportation sector. This sector emits $\sim 1,891$ million metric tons of $\mathrm{CO}_{2}$ per year from petroleum based fuels which is about one third of the total US emissions of 5,900 million metric tons per year. Using this synfuel process would cut our total $\mathrm{CO}_{2}$ production by one-third. We could shift from petroleum-based transportation to synfuel-based. This would reduce our petroleum use by $\sim 75 \%$, and reduce our $\mathrm{CO}_{2}$ production by $\sim 33 \%$ with no sequestration. It would require significant quantities of hydrogen $(\sim 255$ million metric tons/year, or 25 times our current production) that could be produced from splitting of water using solar, wind, or other renewables or nuclear energy.

In addition to significantly reducing our use of petroleum, and cutting our $\mathrm{CO}_{2}$ emissions by one-third, this concept would allow use of our existing hydrocarbonbased transportation infrastructure.

\section{GLOBAL CLIMATE CHANGE \& $\mathrm{CO}_{2}$ EMISSIONS}

Carbon dioxide emissions from the burning of fossil fuels are thought to be causal in global climate change. If this is true, then it is possible to control or slow global climate change by preventing carbon dioxide from entering the atmosphere or by removing what has already been emitted.

We may prevent carbon dioxide from entering the atmosphere by capturing it at its sources and sequestering [storing] it. It can be captured and then stored underground in geologic formations such as deep saline aquifers or depleted gas fields. [Note that some $\mathrm{CO}_{2}$ is used for secondary oil recovery. In this process, $\mathrm{CO}_{2}$ is pumped into an oil field and displaces some of the residual oil left in the field. This process is not generally considered to be sequestration.]

Carbon sequestration is a major program within DOE's Office of Fossil Energy and is now being practiced in several places. One is in the North Sea gas fields at the Sleipner Well. The gas being produced has, as many gas wells do, a significant amount of $\mathrm{CO}_{2}$ in it. In 
the past, such well platforms separated $\mathrm{CO}_{2}$ from the natural gas and vented it to the atmosphere. About 2,800 metric tons of carbon dioxide are separated daily from Sleipner West's gas production and injected into the Utsira sandstone formation (aquifer), 3,000 feet beneath the seabed, for long term storage. While a technical challenge, this is not as difficult a process as separating $\mathrm{CO}_{2}$ from a more dilute stream, such as a flue gas from a conventional pulverized coal power plant, and compressing, transporting and injecting it.

As a rule of thumb, US carbon dioxide emissions are about one third from power, one third from transportation, and the final third from everything else, commonly referred to as "industrial processes." Capturing and sequestering $\mathrm{CO}_{2}$ from fossil-based power plants would reduce US carbon emissions by one third. Power plants provide the best targets for capture and sequestration because they are significant, stationary, point-sources of $\mathrm{CO}_{2}$, and have a limited, common set of operations, making a given capture process easier to accomplish. In contrast, transportation vehicles would require compact onboard separation and storage, a technical challenge, and would need the collection and transport of captured $\mathrm{CO}_{2}$ a logistical hurdle. The remainder of our emissions, the "everything else" category, are from uses that do not have many operations in common and are more diffuse than power plants.

One problem with $\mathrm{CO}_{2}$ capture in the existing fleet of power plants is that they use air to combust the fossil fuel, mainly coal. Air is about $20 \%$ oxygen and $80 \%$ nitrogen, which means that most of the combustion exhaust [flue gas] is atmospheric nitrogen and, consequently, the $\mathrm{CO}_{2}$ is relatively dilute. This is burdensome in that it is more difficult and expensive to remove the $\mathrm{CO}_{2}$ from this stream. In the future, fossil-based power plants will be designed to provide concentrated, sequestration-ready $\mathrm{CO}_{2}$ streams. Some of these advanced plant configurations are being developed and demonstrated under the DOE FutureGen initiative and include Integrated Gasification Combined Cycle plants, chemical looping combustion processes, and Oxyfuel combustion (implemented, for example, by Vattenfall at the Schwarze Pumpe facility in eastern Germany). This last concept separates the air before combustion and only uses the oxygen, providing a flue gas that is mostly $\mathrm{CO}_{2}$ and water. ${ }^{1,2}$ In practice, some of the exhaust $\mathrm{CO}_{2}$ would be recycled to dilute the oxygen during combustion to cool the flame to temperatures similar to existing combustion with air. Note that the exhaust with this scheme is still mostly $\mathrm{CO}_{2}$ and water.

\section{PETROLEUM-BASED FUELS}

Although fossil fuels now provide most of the world's energy, these fuels will become limited in supply and more costly. About $40 \%$ of the U.S. energy demand is met by oil that is converted primarily to liquid transportation fuels (gasoline, diesel, and jet fuel). Today's transportation system depends upon liquid fuels because of their high gravimetric and volumetric energy density and their ease of storage, handling, and transport. Unfortunately, the world is exhausting its resources (Fig. 1) of the light crude oils used to make liquid fuels, with consumption of oil exceeding discoveries since $1985 .^{3}$

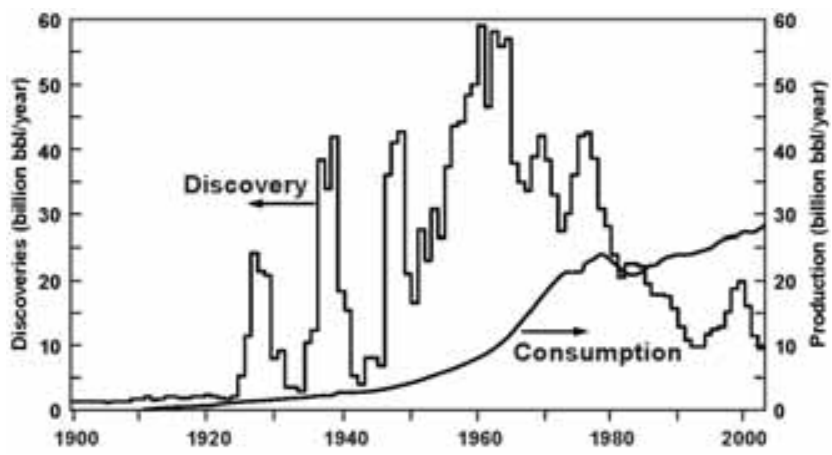

Fig. 1. Rate of world discovery and consumption of conventional crude oils vs. time.

A half-century ago, M. King Hubbert developed a phenomenological model to forecast the peaking of oil production in the lower forty-eight of the United States. This model was principally based on the certainty that the production of a finite resource, e.g., petroleum, will follow a family of bell-shaped curves depending on different initial production rates and estimates of the ultimate size of the resource. He predicted that the year of peak US oil production would be about $1970 .{ }^{4}$ In 1970 , US oil production in fact did peak, confirming the prediction made some fifteen years earlier. According to more pessimistic sources, about half of the world's oil has already been consumed (Fig. 2), while the remaining oil will be increasingly difficult to recover. ${ }^{5,6}$ The peak of the conventional oil supply is predicted to occur in the near-term. Although other sources predict the peak to occur later, most predictions vary by only a decade or so. For a report on this issue commissioned by the U.S. Department of Energy, see reference 6.

Natural gas can be converted to synthetic liquid hydrocarbon fuel and is more plentiful than oil but still limited. The US DOE Energy Information Agency shows US consumption at 22.3 trillion cubic feet (TCF) per year, with proven reserves of 198 TCF ( 9 years' worth) and unproven but expected reserves of 1430 TFC (65 years' worth at the current rate of consumption). ${ }^{7}$ Increasing consumption is already pushing prices up and projected lifetimes down. Coal is plentiful, with supplies said to last hundreds of years at current rates of consumption, but there are environmental costs of mining, transporting, and using coal that must be addressed. Although humankind 
will continue to rely heavily on fossil fuels for its energy needs for much of this century, the challenge during that time must be to find and develop acceptable alternatives. In fact, the U.S. General Accountability Office has released a document expressing its concern with the potential for the global peaking of conventional petroleum production. ${ }^{8}$

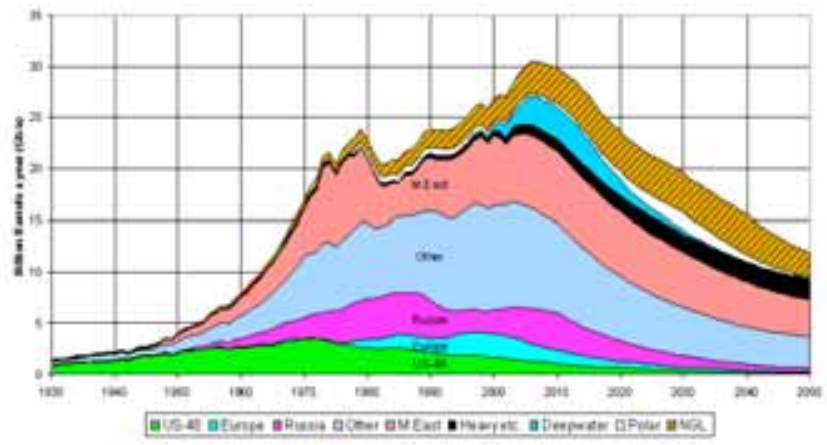

Fig. 2. A prediction of the world oil supply.

\section{SYNTHETIC HYDROCARBON FUELS - "SYNFUEL"}

\section{IV.A. Synfuel by Coal Gasification}

Synthetic liquid hydrocarbons have been synthesized for more than three-quarters of a century from non-liquid feedstocks - principally coal but also natural gas in recent years. The leading process is the Fischer Tropsch (F-T) process which uses synthesis gas - hydrogen and carbon monoxide - as its feed and produces a clean, sulfur- and aromatic-free precursor that is readily processed to a range of commercial finished products using existing petrochemical operations. ${ }^{9}$ The synthesis gas is produced by coal gasification and by reforming of natural gas. Both of these initial conversion processes (in addition to the cost of the feed) can represent a significant cost component of the entire synthesis process. For coal, synthesis gas is produced according to the net reaction: $2 \mathrm{C}+1 / 2 \mathrm{O}_{2}+\mathrm{H}_{2} \mathrm{O} \rightarrow 2 \mathrm{CO}+\mathrm{H}_{2}$. The Water-Gas Shift reaction can be used to produce additional $\mathrm{H}_{2}$ : $\mathrm{CO}+\mathrm{H}_{2} \mathrm{O}$ $\rightarrow \mathrm{H}_{2}+\mathrm{CO}_{2}$ The reaction for producing Fischer-Tropsch products from synthesis gas $\left(\mathrm{CO}\right.$ and $\left.\mathrm{H}_{2}\right)$ is : $\mathrm{CO}+2 \mathrm{H}_{2} \rightarrow$ $\mathrm{CH}_{2}+\mathrm{H}_{2} \mathrm{O}$. Thus, the simultaneous Fischer-Tropsch and Water-Gas Shift reactions in the reactor leads directly to the complete reaction: $2 \mathrm{C}+\mathrm{H}_{2} \mathrm{O}+1 / 2 \mathrm{O}_{2}=\mathrm{CH}_{2}+\mathrm{CO}_{2}$. Note that two carbons are required to produce one Fischer-Tropsch $\mathrm{CH}_{2}$ product with the other carbon being emitted as carbon dioxide.

$$
\begin{array}{ll}
\text { Gasification } & \mathrm{C}+1 / 2 \mathrm{O}_{2}+\mathrm{H}_{2} \mathrm{O} \rightarrow 2 \mathrm{CO}+\mathrm{H}_{2} \\
\text { Water gas shift } & \mathrm{CO}+\mathrm{H}_{2} \mathrm{O} \rightarrow \mathrm{H}_{2}+\mathrm{CO}_{2} \\
\text { F-T reaction } & \mathrm{CO}+2 \mathrm{H}_{2} \rightarrow \mathrm{CH}_{2}+\mathrm{H}_{2} \mathrm{O} \\
\text { Net reaction } & 2 \mathrm{C}+\mathrm{H}_{2} \mathrm{O}+1 / 2 \mathrm{O}_{2} \rightarrow \mathrm{CH}_{2}+\mathrm{CO}_{2}
\end{array}
$$

It should be noted that the above is the theoretical reaction scheme. The actual series of reactions is quite complex but the net result is shown. Note also that the gasification reaction occurs above $2000 \mathrm{~F}$ and the heat for this reaction comes from partial combustion of the carbonaceous feed, be it coal, biomass, or natural gas. This reduces the amount of carbon used to reduce water and increases $\mathrm{CO}_{2}$ production.

\section{IV.B. Synfuel by Coal Gasification + Hydrogen from Water-splitting}

The extra hydrogen that is provided by the WaterGas Shift can be provided by splitting of water with energy supplied from a non- $\mathrm{CO}_{2}$-emitting source. In this case, we still provide synthesis gas as above: $\mathrm{C}+1 / 4 \mathrm{O}_{2}+$ $1 / 2 \mathrm{H}_{2} \mathrm{O} \rightarrow \mathrm{CO}+1 / 2 \mathrm{H}_{2}$ and then provide the extra hydrogen by water-splitting: $3 / 2 \mathrm{H}_{2} \mathrm{O}=3 / 2 \mathrm{H}_{2}+3 / 4 \mathrm{O}_{2}$, for a net reaction of $\mathrm{C}+\mathrm{H}_{2} \mathrm{O}+$ Energy $\rightarrow \mathrm{CH}_{2}+1 / 2 \mathrm{O}_{2}$.

$$
\begin{array}{ll}
\text { Gasification } & \mathrm{C}+1 / 4 \mathrm{O}_{2}+1 / 2 \mathrm{H}_{2} \mathrm{O} \rightarrow \mathrm{CO}+1 / 2 \mathrm{H}_{2} \\
\text { Water-splitting } & 3 / 2 \mathrm{H}_{2} \mathrm{O}+\text { Energy } \rightarrow 3 / 2 \mathrm{H}_{2}+3 / 4 \mathrm{O}_{2} \\
\text { F-T reaction } & \mathrm{CO}+2 \mathrm{H}_{2} \rightarrow \mathrm{CH}_{2}+\mathrm{H}_{2} \mathrm{O} \\
\text { Net reaction } & \mathrm{C}+\mathrm{H}_{2} \mathrm{O}+\text { Energy } \rightarrow \mathrm{CH}_{2}+1 / 2 \mathrm{O}_{2}
\end{array}
$$

In comparison with the conventional gasification and Fischer-Tropsch sequence, only half the carbon is required, and there is no $\mathrm{CO}_{2}$ produced in the conversion process other than the smaller fraction necessary for reaction heat. Further, oxygen is provided by the watersplitting, which avoids the need for an air separation unit for the gasification process, and even has some excess oxygen for potential sale.

\section{IV.C. Synfuel by $\mathrm{CO}_{2}$ Capture $+\mathrm{H}_{2}$ from Water- splitting}

Fossil-fired power plants produce $\mathrm{CO}_{2}$ which could be captured and converted to $\mathrm{CO}$ for production of synthetic fuels. $\mathrm{CO}_{2}$ can be converted to $\mathrm{CO}$ by the Reverse Water Gas Shift Reaction, $\mathrm{CO}_{2}+\mathrm{H}_{2} \rightarrow \mathrm{CO}+$ $\mathrm{H}_{2} \mathrm{O}$. CO could then be used in the F-T reaction with additional hydrogen from water-splitting to produce synfuel. Recent studies using novel reaction schemes, such as membrane reactors, show promise for facile Water-Gas Shift and Reverse Water Gas Shift conversions. $^{10}$

Reverse Water Gas Shift $\quad \mathrm{CO}_{2}+\mathrm{H}_{2} \rightarrow \mathrm{CO}+\mathrm{H}_{2} \mathrm{O}$

F-T reaction $\mathrm{CO}+2 \mathrm{H}_{2} \rightarrow \mathrm{CH}_{2}+\mathrm{H}_{2} \mathrm{O}$

Water-splitting $3 \mathrm{H}_{2} \mathrm{O}+$ Energy $\rightarrow 3 \mathrm{H}_{2}+3 / 2 \mathrm{O}_{2}$

Net reaction $\quad \mathrm{CO}_{2}+\mathrm{H}_{2} \mathrm{O}+$ Energy $\rightarrow \mathrm{CH}_{2}+3 / 2 \mathrm{O}_{2}$ 
In this case, only the coal used to produce power is needed, and the resulting $\mathrm{CO}_{2}$ is consumed rather than released. The excess $\mathrm{O}_{2}$ would be used as Oxyfuel in the fossil power plant that provides the $\mathrm{CO}_{2}$, simplifying $\mathrm{CO}_{2}$ capture. Figure 3 illustrates the complete block diagram for an idealized process.

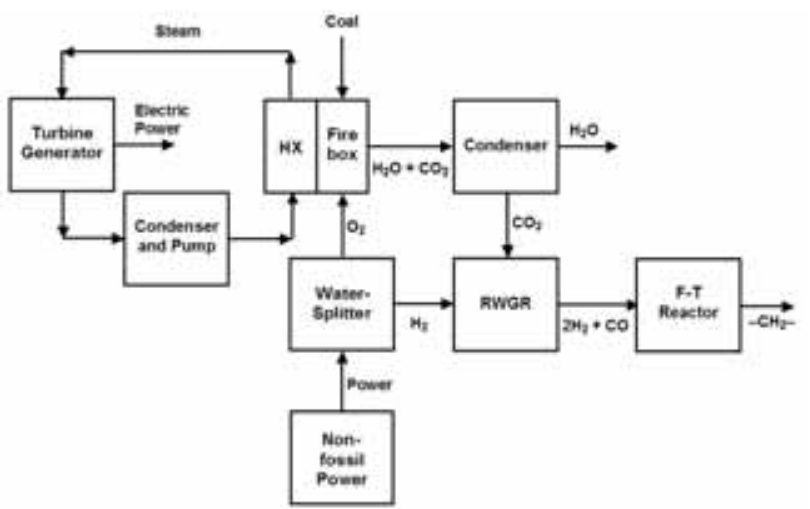

Fig. 3. Oxyfuel Coal Plant and Fischer-Tropsch Processes Augmented with Externally Provided Oxygen and Hydrogen Produced by Water-Splitting.

There is currently considerable effort underway on developing $\mathrm{CO}_{2}$ capture systems for new and extant power plants. In previous papers, we have discussed Membrane Gas Absorption approaches for retrofitting existing coal power plants for post-combustion $\mathrm{CO}_{2}$ capture $^{11,12}$ and this material will not be reproduced here. Rather we will focus on the Oxyfuel configuration as shown in Figure 3 as there is reasonable optimism that some existing pulverized coal (PC) plants may be retrofittable because of the considerably smaller gas-flow due to the absence of nitrogen.

Such a synergistic system, as described above, dubbed "twice burned coal" or "recycled coal," has the potential to significantly reduce our current emissions of $\mathrm{CO}_{2}$ since the carbon in the coal is used once for power production and then again for liquid hydrocarbon fuel synthesis. Fig. 4 illustrates the Crystal River plant, owned and operated by Progress Energy, that has four PC plants rated at 2,313 $\mathrm{MW}_{\mathrm{e}}$, total and one nuclear plant rated at $838 \mathrm{MW}_{\mathrm{e}}$. For the twice-burned coal case, there would be one Oxyfueled plant rated at $\sim 400 \mathrm{MW}_{\mathrm{e}}$ net output and two nuclear plants rated at $\sim 2,270 \mathrm{MW}_{\mathrm{e}}$ (total) for fuel production. This plant would produce $\sim 790,800$ gallons per day of motor fuel. Serendipitously, this would be the demand of each energy form for about 200,000 households.

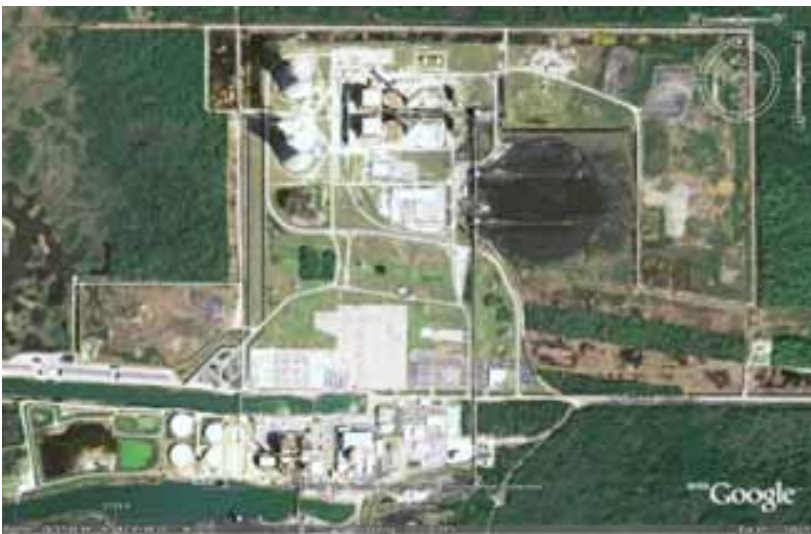

Fig. 4. The Progress Energy Crystal River Facility with 4 Pulverized Coal Plants and 1 Nuclear Plant.

\section{ECONOMIC ESTIMATES}

While the concept of using an external source of hydrogen to reduce or even eliminate $\mathrm{CO}_{2}$ production while making synfuel is exciting, the economics have to be reasonable. We did some simple analyses to explore the economics.

TABLE 1 - 400 MWe Oxyfuel Plant Cost Basis and COE

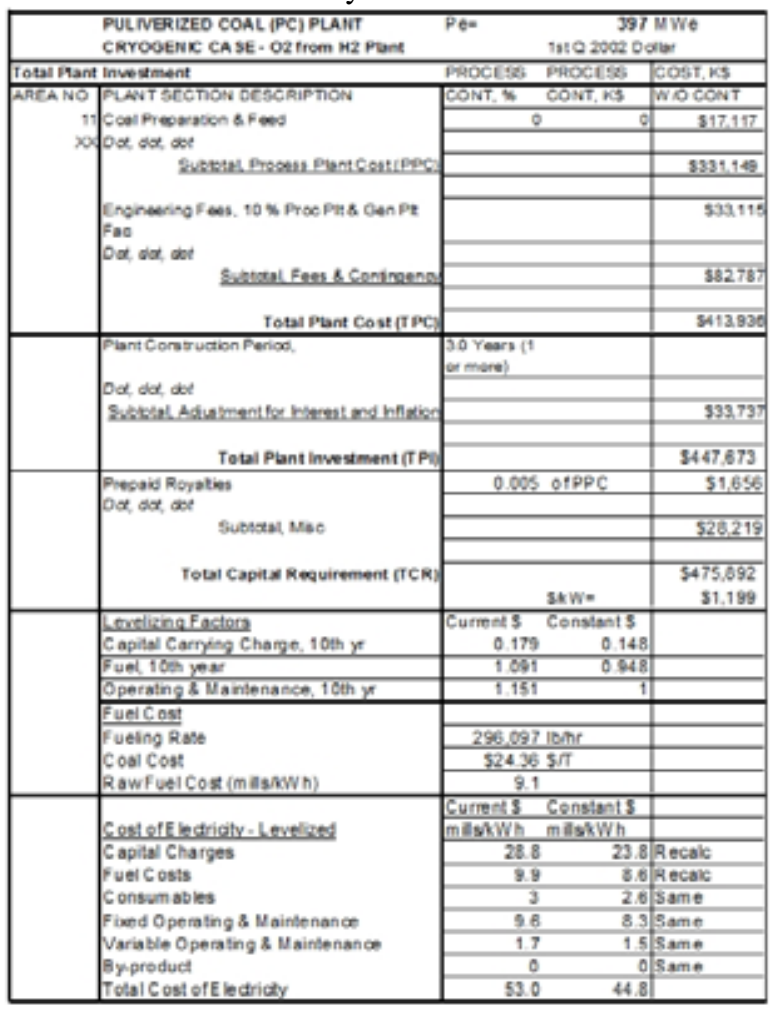

For the Oxyfueled PC plant, we used the cost basis presented by the Department of Energy's National Energy Technology Laboratory ${ }^{13}$ and reproduced above, in Table 1 , with the ASU and the $\mathrm{CO}_{2}$ compressor costs and power 
requirements eliminated. Because of this, the $\mathrm{COE}$ is virtually identical to that associated with a PC plant that rejects its $\mathrm{CO}_{2}$ into the atmosphere. However, in this case, the synfuel plant takes all of the $\mathrm{CO}_{2}$ and converts it to transportation fuel. Note the levelizing factors in the table (17.9\% for current $\$$ and $14.8 \%$ for constant $\$$ ) are typical for an investor-owned utility. Below, we will look at this in terms of the cost of capital for Public and Private sector investment.

Previous work on the hydrogen-assisted CTL process, briefly discussed in section IV.A., was based on a scoping study performed by Rentech for the state of Wyoming for synthetic diesel fuel and electricity production from Powder River Basin coal using coal gasification and the Fischer-Tropsch synthesis process. ${ }^{14}$ For their baseline economic assumptions, they estimate the cost of synfuel production, including both capital and operating costs, at $\$ 0.95 /$ gallon. The baseline assumptions include coal at $\$ 5.00 /$ ton and a $6.5 \%$ cost of capital. Adjusting these to more realistic values of $\$ 30 /$ ton for coal and $10 \%$ (Public Sector) interest raises the cost of synfuel to $\sim \$ 1.85 /$ gallon, still a reasonable cost. However, this plant would emit to the atmosphere about $20 \mathrm{~kg}$ of $\mathrm{CO}_{2}$ for each gallon of fuel it is to produce. Should this cost be internalized, it would amount to $\sim \$ 0.60$ per gallon.

For this analysis, we adopted the cost figures that were offered in the Rentech presentation only for the Fischer-Tropsch part of their plant as the remainder of the plant is related to coal processing and electricity production. We further assumed that a reverse water gas shift reaction system would have approximately the same cost characteristics as the F-T component since the volumetric flow rates and thermodynamic properties are similar. We then estimated the benefit of getting the oxygen and hydrogen needed for the entire process from nuclear power (the baseline carbon-free sustainable energy technology we selected for this analysis).

The cost of the oxygen and hydrogen was estimated for production using the Sulfur-Iodine thermochemical water-splitting process coupled to the Modular Helium Reactor, ${ }^{15}$ and also for production by standard low temperature electrolysis using electricity from a Light Water Reactor. Table 2 presents the results of this analysis for two Capital Recovery Factors (10\% and 15\%) and Nominal \& Low plant costs (for the electrolyser efficiency, Nominal is $54.7 \mathrm{kWh} / \mathrm{kg}$ of $\mathrm{H}_{2}$ and Low is $49.2 \mathrm{kWh} / \mathrm{kg}$ of $\mathrm{H}_{2}$ ).
TABLE 2. Estimated Cost of Synfuel, \$/gallon (without/with \$30/tonne $\mathrm{CO}_{2}$ Consumption credit; with Additional \$30/tonne Avoided $\mathrm{CO}_{2}$ Credit With Respect to the Rentech Plant).

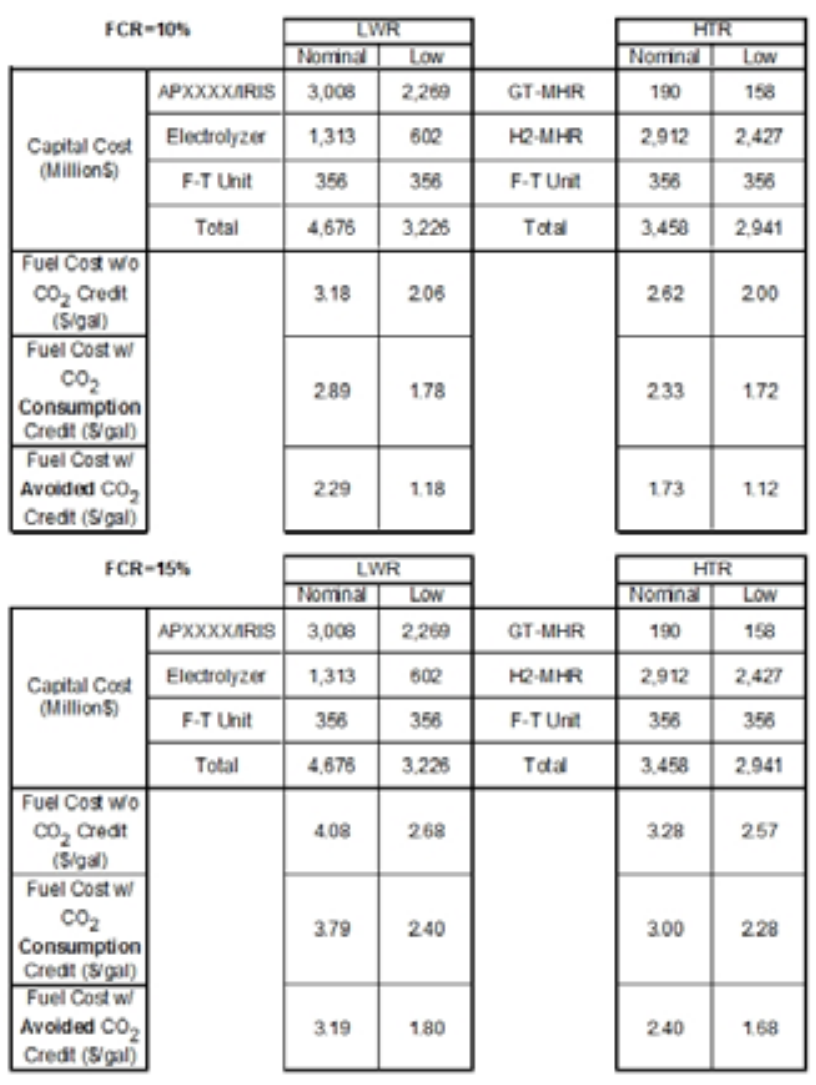

Consider first the effect of the Interest Rate (Fixed Charge Rate or Capital Carrying Charge in Table 2). The effect of the Carrying Charge on the cost of the fuel product is striking, especially for the highest capital cost plant (Nominal LWR plant). Even for the lowest capital cost plant (Low HTR), it is still significant. Consequently, for economic competitiveness, it is very desirable to fund such a plant as a Public/Private enterprise in order to obtain the lowest possible capital charge. There are both large and small scale examples of such partnerships that span the range from a "TVA" to a multiplicity of Municipal utilities.

Next, it is important to note that the cost of the hydrogen/oxygen production system dominates the capital cost. This is not surprising as both hydrogen and high quality thermal/electrical technologies are expensive. It is especially noted that there is considerable incentive to reduce the cost and increase the efficiency of electrolyser systems for nearer-term deployment.

It is almost a "given" now that the costs associated with reducing (consuming) $\mathrm{CO}_{2}$ emissions will be 
internalized in the next few years. So, the rows of data that reduce the "raw" cost by the $\$ 30 /$ Tonne of $\mathrm{CO}_{2}$ are realistic. How this charge eventually will be internalized is still uncertain. Should it be a "tax" to penalize $\mathrm{CO}_{2}$ emitters rather than a credit given as offsets (tradable in a market), then these cost reductions may not materialize. However, then the cost of coal-based synfuel would rise an equivalent amount.

In addition there is the interesting discussion containing further cost reductions called Avoided $\mathrm{CO}_{2}$. In this case, we use as a baseline the Rentech plant discussed above and compare our system to it. The justification is that the Rentech plant is what one would build today if CTL plants had to be built. Comparing the plant types side by side, we see that the Rentech plant is a net producer of $\mathrm{CO}_{2}(\sim 20 \mathrm{~kg} / \mathrm{gal})$ and our plant is a net consumer of $\mathrm{CO}_{2}(\sim 9.6 \mathrm{~kg} / \mathrm{gal})$. While it is not clear that such a credit might be taken, it draws a very compelling distinction between the two concepts.

Finally, it is worth noting the rows of costs in $10 \%$ FCR / $\mathrm{CO}_{2}$ Consumption case. It is very reasonable to assume that "tenth-of-a-kind" plant capital costs will lie in the "Low" cost range. Should this be the case, then the LWR system and HTR systems would produce fuels very likely below $\$ 2.00$ per gallon.

\section{SYSTEMS ANALYSIS}

The overall impact of alternative sources of transportation fuels can be seen by examining the $\mathrm{CO}_{2}$ flows resulting from energy consumption. ${ }^{16}$ Our current total US emission is 5,682 million metric tonnes (MMt)/yr. Our petroleum-based transportation economy releases 1,811 $\mathrm{MMt}$ of $\mathrm{CO}_{2}$ per year. Approximately another $100 \mathrm{MMt}$ of $\mathrm{CO}_{2}$ are released in the production and processing of that petroleum for at total of 1911 MMt/yr. See Table 3.

If this petroleum based transportation economy were replaced by a coal-based economy using coal gasification and Fischer-Tropsh conversion, the consumption of coal would be tripled to $1678 \mathrm{MMt}$ / year of $\mathrm{C}$ as coal, and the production of $\mathrm{CO}_{2}$ from transportation doubled to 3857 MMt/yr.

If a $\mathrm{CO}_{2}$-free source of hydrogen, such as nuclear or solar energy, is provided, production of synfuels could be done using $556 \mathrm{MMt} / \mathrm{yr}$ of carbon as coal and producing 1,905 MMt/yr of $\mathrm{CO}_{2}$. This would mean doubling our current consumption of coal but with no increase in our current production of $\mathrm{CO}_{2}$ as the coal based fuels would displace petroleum. If the carbon needed for synfuel were provided from $\mathrm{CO}_{2}$ captured from flue gas of our current coal-fired power plants (the focus of this paper), the mass flows match well. About $565 \mathrm{MMt} / \mathrm{yr}$ of carbon is used and released in the form of $\mathrm{CO}_{2}$, and about $565 \mathrm{MMt} / \mathrm{yr}$ is needed for synfuel production. We could provide all of our transportation fuel using $\mathrm{CO}_{2}$ captured from our current coal-fired power plants. This would require no additional coal use and would actually cut our current release of $\mathrm{CO}_{2}$ by one-third. Both these scenarios would require a significant increase in the amount of hydrogen that would have to be produced, and would require development of non- $\mathrm{CO}_{2}$ emitting techniques, such as commercial water splitting, for its production. These alternate scenarios are summarized on Table 3.

TABLE 3. Fuel Needed and $\mathrm{CO}_{2}$ Released for Alternate Transportation Fuel Sources

\begin{tabular}{|c|c|c|c|c|}
\hline \multirow[b]{2}{*}{ Units: MMt/yr } & \multicolumn{4}{|c|}{ Transportation Fuel From } \\
\hline & Oil & Coal & $\begin{array}{l}\text { Coal }+ \\
\mathrm{H}_{2} \\
\text { from } \\
\text { water }\end{array}$ & $\begin{array}{l}\mathrm{CO}_{2}+ \\
\mathrm{H}_{2} \\
\text { from } \\
\text { water }\end{array}$ \\
\hline Oil needed & 612 & -- & -- & -- \\
\hline Coal needed & -- & 1113 & 556 & 0 \\
\hline $\mathrm{H}_{2}$ needed & -- & -- & 130 & 260 \\
\hline $\mathrm{CO}_{2}$ produced & $\sim 100$ & 2046 & 104 & -1811 \\
\hline $\begin{array}{l}\mathrm{CO}_{2} \text { released on } \\
\text { use }\end{array}$ & 1811 & 1811 & 1811 & 1811 \\
\hline Net $\mathrm{CO}_{2}$ released & 1911 & 3857 & 1905 & 0 \\
\hline \multicolumn{5}{|c|}{$\begin{array}{l}\text { Current total } \mathrm{CO}_{2} \text { production: } 5,682 \mathrm{MMt} / \mathrm{yr} \\
\text { Current } \mathrm{C} \text { as coal use } / \mathrm{CO}_{2} \text { produced: } 565 / 2070 \\
\mathrm{MMt} / \mathrm{yr}, \mathrm{H}_{2} \text { use: } 10 \mathrm{MMt} / \mathrm{yr}\end{array}$} \\
\hline
\end{tabular}

\section{CONCLUSIONS}

Production of synthetic hydrocarbon fuels can help with our growing dependence on declining petroleum. In production of synfuels from coal, one atom of carbon is produced as $\mathrm{CO}_{2}$ for every atom produced as $\mathrm{CH}_{2}$ in the synfuel. If hydrogen is provided from an external, nonfossil source, such as solar, wind or nuclear production of hydrogen from water, the synfuel production process need not produce any $\mathrm{CO}_{2}$. However, the synfuel, when burned for transportation will produce and release the contained carbon as $\mathrm{CO}_{2}$. Since the synfuel would be a replacement for petroleum-based fuel, there would be no net increase in the production or release of $\mathrm{CO}_{2}$. If the hydrogen is provided from an external, non-fossil source, and if the carbon is provided by capture of $\mathrm{CO}_{2}$ from existing coalfired power plants, the total U.S. release of $\mathrm{CO}_{2}$ can be reduced by one-third. Hydrogen would be used to produce $\mathrm{CO}$ from $\mathrm{CO}_{2}$ in the reverse water gas shift reaction and to produce $\left[\mathrm{CH}_{2}\right]_{n}$ from $\mathrm{CO}$ and $\mathrm{H}_{2}$ in the Fischer-Tropsch reaction. Three molecules of $\mathrm{H}_{2}$ would be needed for every moiety of $\mathrm{CH}_{2}$ produced. 
The production rate of $\mathrm{CO}_{2}$ from coal power plants in the US is 1,891 million metric tons/year. If this $\mathrm{CO}_{2}$ were captured using proven extraction processes and used with hydrogen produced by solar, wind or nuclear energy to make synfuel, it would provide all the hydrocarbon fuel needed for our transportation sector. Since transportation produces 1,911 million metric tons of $\mathrm{CO}_{2}$ per year, this synfuel process would cut our $\mathrm{CO}_{2}$ production by onethird while still using our existing hydrocarbon-based transportation infrastructure. We could shift from a petroleum-based transportation sector to a synfuel-based transportation sector. This would reduce our petroleum use by $75 \%$, and reduce our $\mathrm{CO}_{2}$ production by $33 \%$. It would require significant quantities of hydrogen (260 million metric tons/year, or 25 times our current production) that would be produced from water using solar, wind or nuclear energy.

Our economics estimates indicate that use of hydrogen in the synfuel production process from power plant $\mathrm{CO}_{2}$ capture appears to be practical and may be required to help mitigate climate change, and would allow synfuel to be produced with only minor cost increase over coal-based synfuel production.

Earlier work (references 11 and 12) revealed the further potential for the production of synthetic fuel with $\mathrm{CO}_{2}$ extracted from the atmosphere which is envisioned to be the longer-term goal of our current research. The hydrogen production infrastructure needed for synfuel production could also be used to produce hydrogen for direct application via fuel cells in the future. A hydrogensynfuel economy could provide a bridge to a future pure hydrogen economy.

\section{ACKNOWLEDGMENTS}

This work was supported by General Atomics' internal R\&D funds.

\section{REFERENCES}

\footnotetext{
${ }^{1}$ M. Landler, "Europe's Image Clashes With Reliance on Coal,” New York Times, June 20, 2006.

${ }^{2}$ T. Folger, "Can Coal Come Clean?” Discover. Vol. 27 No. 12, December 2006.

${ }^{3}$ P. R. A. WELLS, “Oil Supply Challenges-1: The NonOPEC Decline," Oil and Gas Journal, 20-28 (February 21, 2005).

${ }^{4}$ M. King Hubbert, "Nuclear Energy and the Fossil Fuels," Publication No. 95, Shell Development Company, 1956.
}

${ }^{5}$ Association for the Study of Peak Oil, available at http://www.peakoil.net.

${ }^{6}$ R.L. Hirsch, R. Bezdek and R. Wendling, "Peaking of World Oil Production: impacts, mitigation and risk management," Feb. 2005, available at http://www.netl.doe.gov/otiic - "World Oil Issues". ${ }^{7}$ U.S. DOE Energy Information Agency: http://www.eia.doe.gov - "Natural Gas"

8 “CRUDE OIL - Uncertainty about Future Oil Supply

Makes It Important to Develop a Strategy for Addressing a Peak and Decline in Oil Production," GAO-07-283, February 1007.

${ }^{9}$ For an exhaustive review of the Fischer-Tropsch process, Syntroleum Inc. sponsors a website:

http://www.fischer-tropsch.org/.

${ }^{10}$ Bustamante, Enick, Killmeyer, Howard, Rothenberger, Cugini, Morreale, Ciocco, "Uncatalyzed and wallcatalyzed forward water-gas shift reaction kinetics", AIChE Journal, 51-5 (2005) 1440, also Bustamante, Enick, Cugini, Killmeyer, Howard, Rothenberger, Ciocco, Morreale, Chattopadhyay, Shi, "High-temperature kinetics of the homogeneous reverse water-gas shift reaction", AIChE Journal, 50-5 (2004) 1028.

${ }^{11}$ K.R. Schultz and S.L. Bogart, et. al., "Hydrogen and Synthetic Hydrocarbon Fuels - a Natural Synergy," National Hydrogen Association Annual Meeting, 13-16 March 2006, Long Beach, CA.

${ }^{12}$ S.L. Bogart and K.R. Schultz, "Production of Liquid Synthetic Hydrocarbon Fuels From Air, Water, and Nuclear Power on Ships and at Shore Bases for Military Use," ICAPP'06, Reno NV, June 2006.

${ }^{13}$ E. L. Parsons, et. al., "Advanced Fossil Power Systems Comparison Study,” National Energy Technology Laboratory and EG\&G Technical Services, Inc., December, 2002.

${ }^{14}$ http://www.rentechinc.com/process-technicalpublications.htm Presentation to the Wyoming Governor's Office and the Wyoming Business Council, April 14, 2005 Cheyenne, Wyoming.

${ }^{15}$ K. R. Schultz, et. al, "Large-Scale Production of Hydrogen by Nuclear Energy for the Hydrogen Economy," National Hydrogen Association Annual Meeting, 2003.

${ }^{16} \mathrm{http}$ ://eed.1lnl.gov/flow/ "US 2002 Carbon Dioxide Emissions from Energy Consumption," Lawrence Livermore National Laboratory. 